Original Research Paper

\title{
Forces of a 3R Robot
}

\author{
${ }^{1}$ Relly Victoria Petrescu, ${ }^{2}$ Raffaella Aversa, ${ }^{3}$ Bilal Akash, \\ ${ }^{2}$ Antonio Apicella and ${ }^{1}$ Florian Ion Tiberiu Petrescu \\ ${ }^{I}$ ARoTMM-IFToMM, Bucharest Polytechnic University, Bucharest, (CE), Romania \\ ${ }^{2}$ Advanced Material Lab, Department of Architecture and Industrial Design, \\ Second University of Naples, 81031 Aversa (CE), Italy \\ ${ }^{3}$ Dean of School of Graduate Studies and Research, American University of Ras Al Khaimah, UAE
}

Corresponding Author:

Florian Ion Tiberiu Petrescu

ARoTMM-IFToMM, Bucharest

Polytechnic University,

Bucharest, (CE), Romania

E-mail: scipub02@gmail.com

\begin{abstract}
In this study, one presents a method for determination of kinetostatic parameters in dyad $3 R$. It starts with the determination of the forces in the joints: $R_{B}, R_{D}, R_{23}$. To generalize the method including for the $2 \mathrm{R}$ robots, enter both the moments $M_{1}, M_{2}$. This module (2R) is the main module found in all rotating anthropomorphic robotic structures and similar mechatronic structures. If there are additional external forces such as technological resistances, they will also be added. The forces acting within a mechanism are of particular importance in that they give the dimensions of the mechanism, the elements of the mechanism so that it can withstand all the static and dynamic loads during its operation. For this reason, it is important to know all the forces acting on the elements but especially on the kinematic couplers, both for the correct dimensioning of these elements and for the proper functioning of the respective mechanism. Forces together with kinematics are, on the other hand, basic components of dynamic calculations for that mechanism. This is also true for robots. Science that deals with the determination of forces within a mechanism is called Kinetostatic. The calculations within a mechanism are made on the pieces of this mechanism called structural groups or structural modulus. The structural modules of a mechanism are determined on the basis of the principle of eliminating the mobility of the respective group in the desmodromic mechanisms. The mobility of the mechanism is given either by other movable input elements that are added to the structural groups or to the robots by adding some actuators to the elements of a module.
\end{abstract}

Keywords: 3R Dyad, Kinetostatic Parameters, External Forces, Internal Forces

\section{Introduction}

The forces acting within a mechanism are of particular importance in that they give the dimensions of the mechanism, the elements of the mechanism so that it can withstand all the static and dynamic loads during its operation. For this reason, it is important to know all the forces acting on the elements but especially on the kinematic couplers, both for the correct dimensioning of these elements and for the proper functioning of the respective mechanism. Forces together with kinematics are, on the other hand, basic components of dynamic calculations for that mechanism. This is also true for robots. Science that deals with the determination of forces within a mechanism is called Kinetostatic (Antonescu and Petrescu, 1985; 1989; Antonescu et al.,
$1985 \mathrm{a} ; 1985 \mathrm{~b} ; 1986 ; 1987 ; 1988 ; 1994 ; 1997 ; 2000 \mathrm{a}$; 2000b; 2001; Aversa et al., 2017a; 2017b; 2017c; 2017d; $2017 \mathrm{e}$; 2016a; 2016b; 2016c; 2016d; 2016e; 2016f; 2016g; 2016h; 2016i; 2016j; 2016k; 2016l; 2016m; 2016n; 2016o; Berto et al., 2016a; 2016b; 2016c; 2016d; Cao et al., 2013; Dong et al., 2013).

The calculations within a mechanism are made on the pieces of this mechanism called structural groups or structural modulus.

The structural modules of a mechanism are determined on the basis of the principle of eliminating the mobility of the respective group in the desmodromic mechanisms. The mobility of the mechanism is given either by other movable input elements that are added to the structural groups or to the robots by adding some actuators to the elements of a module (Fig. 1). 


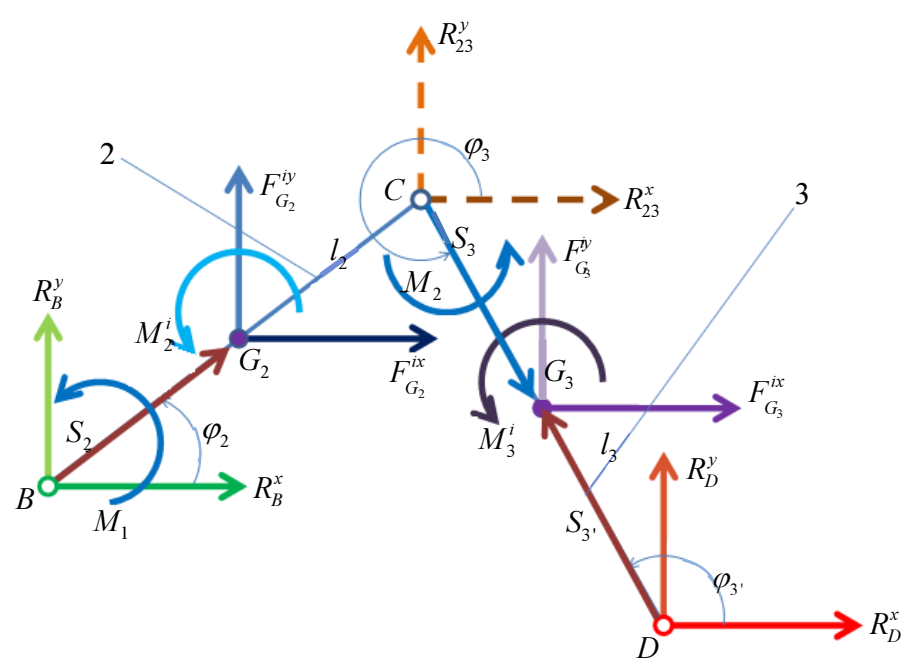

Fig. 1: The kinetostatic parameters to a $3 R$ dyad ( $2 R$ module)

\section{Materials and Methods}

In this study it presents a method able to determine the kinetostatic parameters to a $3 \mathrm{R}$ dyad (Fig. 1) (Comanescu, 2010; Franklin, 1930; He et al., 2013; Lee, 2013; Lin et al., 2013; Liu et al., 2013; Mirsayar et al., 2017; Padula and Perdereau, 2013; Perumaal and Jawahar, 2013; Petrescu, 2011; 2015a; 2015b; Petrescu and Petrescu, 1995a; 1995b; 1997a; 1997b; 1997c; 2000a; 2000b; 2002a; 2002b; 2003; 2005a; 2005b; 2005c; 2005d; 2005e; 2011; 2012a; 2012b; 2013a; 2013b; 2016a; 2016; 2016c; Petrescu et al., 2009; 2016; 2017a; 2017b; 2017c; 2017d; 2017e; 2017f; 2017g; 2017h;2017i; 2017j; 2017k; 2017l).

To generalize the method and to the $2 \mathrm{R}$ robots, are introduced and the two moments $M_{1}, M_{2}$. This $2 \mathrm{R}$ module, is the principal from the android rotation robotic structures and mechatronic structures.

The $3 \mathrm{R}$ dyad has two elements, noted with 2 and 3. Their lengths are $l_{2}$ and $l_{3}$.

If the $3 \mathrm{R}$ dyad is coupling to a $4 \mathrm{R}$ mechanism, we note the forces which give the entry into dyad, with $R_{12}$ and $R_{03}$. In case the structure 2-3 is using to a robot or to another mechanism, we note the entrance forces, with $R_{B}$ and $R_{D}$.

One proposes to determine the forces from joints: $R_{B}$, $R_{D}, R_{23}$.

Figure 1 shows a schematic diagram of the $3 \mathrm{R}$ dyad minimum kinetostatic (loaded with the inertia forces, considered external forces).

For if there are additional external forces, such as technological resistances will be added as well.

One can consider and the forces of gravity, if mechanism operates strictly vertically and working speeds are low.

\section{Determining the Forces from Joints}

The joints forces represent the interior loads (internal forces).

One proposes to determine these (internal) forces.
We start with the internal force $R_{B}$, which is divided in two components in a Cartesian planar system: $R_{B}^{x}, R_{B}^{y}$.

If external forces are known in general (are given, determined, calculated), internal forces (reactions of kinematic couplings) results from the balance of forces and moments of the dyad.

To start we are writing an equation representing the sum of the moments from element 2 in relation to the point $C$ and another relationship which represent the sum of all moments from entire dyad, in relation to the point $D$ (system 1).

$$
\left\{\begin{array}{l}
\sum M_{C}^{(2)}=0 \Rightarrow R_{B}^{x} \cdot\left(y_{C}-y_{B}\right)- \\
R_{B}^{y} \cdot\left(x_{C}-x_{B}\right)+M_{1}+ \\
+F_{G_{2}}^{i x} \cdot\left(y_{C}-y_{G_{2}}\right)- \\
-F_{G_{2}}^{i y} \cdot\left(x_{C}-x_{G_{2}}\right)+M_{2}^{i}=0 \\
\sum M_{D}^{(2,3)}=0 \Rightarrow R_{B}^{x} \cdot\left(y_{D}-y_{B}\right)- \\
-R_{B}^{y} \cdot\left(x_{D}-x_{B}\right)+M_{1}+ \\
+F_{G_{2}}^{i x} \cdot\left(y_{D}-y_{G_{2}}\right)-M_{2}^{i}+M_{2}+ \\
-F_{G_{2}}^{i y} \cdot\left(x_{D}-x_{G_{2}}\right)+M_{3}^{i}+ \\
+F_{G_{3}}^{i x} \cdot\left(y_{D}-y_{G_{3}}\right)- \\
-F_{G_{3}}^{i y} \cdot\left(x_{D}-x_{G_{3}}\right)=0
\end{array}\right.
$$

The two equations are rewritten in the form of the system (2):

$$
\left\{\begin{array}{l}
\left(y_{C}-y_{B}\right) \cdot R_{B}^{x}-\left(x_{C}-x_{B}\right) \cdot R_{B}^{y}=-M_{1}- \\
-F_{G_{2}}^{i x} \cdot\left(y_{C}-y_{G_{2}}\right)+F_{G_{2}}^{i y} \cdot\left(x_{C}-x_{G_{2}}\right)-M_{2}^{i} \\
\left(y_{D}-y_{B}\right) \cdot R_{B}^{x}-\left(x_{D}-x_{B}\right) \cdot R_{B}^{y}= \\
=-M_{1}-F_{G_{2}}^{i x} \cdot\left(y_{D}-y_{G_{2}}\right)+ \\
+F_{G_{2}}^{i y} \cdot\left(x_{D}-x_{G_{2}}\right)-M_{2}^{i}-M_{2}- \\
-F_{G_{3}}^{i x} \cdot\left(y_{D}-y_{G_{3}}\right)+F_{G_{3}}^{i y} \cdot\left(x_{D}-x_{G_{3}}\right)-M_{3}^{i}
\end{array}\right.
$$


System (2) can be arranged as a linear system (3) by two equations with two unknowns $R_{12}^{x} \equiv R_{B}^{x} ; R_{12}^{y} \equiv R_{B}^{y}$, with the coefficients, given from system (4):

$$
\left\{\begin{array}{l}
\left\{\begin{array}{l}
a_{11} \cdot R_{12}^{x}+a_{12} \cdot R_{12}^{y}=a_{1} \\
a_{21} \cdot R_{12}^{x}+a_{22} \cdot R_{12}^{y}=a_{2}
\end{array}\right. \\
\text { or } \\
\left\{\begin{array}{l}
a_{11} \cdot R_{B}^{x}+a_{12} \cdot R_{B}^{y}=a_{1} \\
a_{21} \cdot R_{B}^{x}+a_{22} \cdot R_{B}^{y}=a_{2}
\end{array}\right.
\end{array}\right.
$$

$$
\left\{\begin{array}{l}
a_{11}=y_{C}-y_{B} ; a_{12}=-\left(x_{C}-x_{B}\right) ; \\
a_{1}=-M_{1}-F_{G_{2}}^{i x} \cdot\left(y_{C}-y_{G_{2}}\right)+ \\
+F_{G_{2}}^{i y} \cdot\left(x_{C}-x_{G_{2}}\right)-M_{2}^{i} \\
a_{21}=y_{D}-y_{B} ; a_{22}=-\left(x_{D}-x_{B}\right) ; \\
a_{2}=-M_{1}-F_{G_{2}}^{i x} \cdot\left(y_{D}-y_{G_{2}}\right)+F_{G_{2}}^{i j} \cdot\left(x_{D}-x_{G_{2}}\right)- \\
-M_{2}^{i}-M_{2}--F_{G_{3}}^{i x} \cdot\left(y_{D}-y_{G_{3}}\right)+ \\
+F_{G_{3}}^{i y} \cdot\left(x_{D}-x_{G_{3}}\right)-M_{3}^{i}
\end{array}\right.
$$

Solutions of the system (3) will be given by system (5):

$$
\left\{\begin{array}{l}
\Delta=\left|\begin{array}{l}
a_{11} a_{12} \\
a_{21} a_{22}
\end{array}\right|=a_{11} \cdot a_{22}-a_{12} \cdot a_{21} \\
\Delta_{x}=\left|\begin{array}{l}
a_{1} a_{12} \\
a_{2} a_{22}
\end{array}\right|=a_{22} \cdot a_{1}-a_{12} \cdot a_{2} \\
\Delta_{y}=\left|\begin{array}{l}
a_{11} a_{1} \\
a_{21} a_{2}
\end{array}\right|=a_{11} \cdot a_{2}-a_{21} \cdot a_{1} \\
R_{B}^{x} \equiv R_{12}^{x}=\frac{\Delta_{x}}{\Delta}=\frac{a_{22} \cdot a_{1}-a_{12} \cdot a_{2}}{a_{11} \cdot a_{22}-a_{12} \cdot a_{21}} ; \\
R_{B}^{y} \equiv R_{12}^{y}=\frac{\Delta_{y}}{\Delta}=\frac{a_{11} \cdot a_{2}-a_{21} \cdot a_{1}}{a_{11} \cdot a_{22}-a_{12} \cdot a_{21}}
\end{array}\right.
$$

Further determine other two internal forces, $R_{03}^{x} s i R_{03}^{y}$, or $\left(R_{D}^{x} \operatorname{si} R_{D}^{y}\right)$.

Next we write the sum of all forces on the dyad $(2,3)$ designed separately, first on the $x$ axis and then on the $y$ axis, (see the system 6).

$$
\left\{\begin{array}{l}
\sum F_{x}^{(2,3)}=0 \Rightarrow \\
\Rightarrow R_{12}^{x}+F_{G_{2}}^{i x}+F_{G_{3}}^{i x}+R_{03}^{x}=0 \Rightarrow \\
\Rightarrow R_{D}^{x} \equiv R_{03}^{x}=-R_{12}^{x}-F_{G_{2}}^{i x}-F_{G_{3}}^{i x} \\
\sum F_{y}^{(2,3)}=0 \Rightarrow \\
\Rightarrow R_{12}^{y}+F_{G_{3}}^{i y}+F_{G_{3}}^{i y}+R_{03}^{y}=0 \Rightarrow \\
\Rightarrow R_{D}^{y} \equiv R_{03}^{y}=-R_{12}^{y}-F_{G_{2}}^{i y}-F_{G_{3}}^{i y}
\end{array}\right.
$$

$$
\begin{aligned}
& \left\{\begin{array}{l}
\left\{\begin{array}{l}
\sum F_{x}^{(2)}=0 \Rightarrow R_{12}^{x}+F_{G_{2}}^{i x}- \\
-R_{23}^{x}=0 \Rightarrow R_{23}^{x}=R_{12}^{x}+F_{G_{2}}^{i x} \\
\sum F_{y}^{(2)}=0 \Rightarrow R_{12}^{y}+F_{G_{2}}^{i y}-
\end{array}\right. \\
\text { or }\left\{\begin{array}{l}
\sum F_{23}^{y}=0 \Rightarrow R_{23}^{y}=R_{12}^{y}+F_{G_{2}}^{i y} \\
+R_{D}^{x}=0 \Rightarrow R_{23}^{x}=-F_{G_{3}}^{x}+ \\
\sum F_{y}^{(3)}=0 \Rightarrow R_{23}^{y}+F_{G_{3}}^{i y}+R_{D}^{x} \\
+R_{D}^{y}=0 \Rightarrow R_{23}^{y}=-F_{G_{3}}^{i y}-R_{D}^{y}
\end{array}\right.
\end{array}\right.
\end{aligned}
$$

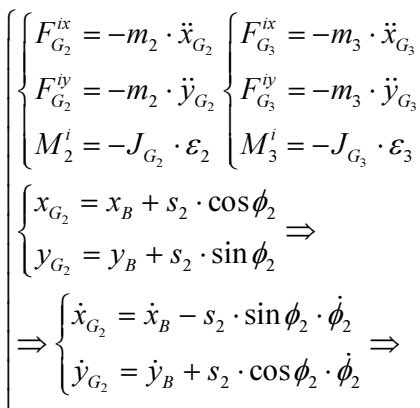

$$
\begin{aligned}
& \left\{\Rightarrow \left\{\begin{array}{l}
\ddot{x}_{G_{2}}=\ddot{x}_{B}-s_{2} \cdot \cos \phi_{2} \cdot \omega_{2}^{2}-s_{2} \cdot \sin \phi_{2} \cdot \varepsilon_{2} \\
\ddot{y}_{G_{2}}=\ddot{y}_{B}-s_{2} \cdot \sin \phi_{2} \cdot \omega_{2}^{2}+s_{2} \cdot \cos \phi_{2} \cdot \varepsilon_{2}
\end{array}\right.\right. \\
& \left\{\begin{array}{l}
x_{G_{3}}=x_{D}+s_{3^{\prime}} \cdot \cos \phi_{3^{\prime}} \\
y_{G_{3_{3}}}=y_{D}+s_{3^{\prime}} \cdot \sin \phi_{3^{\prime}}
\end{array} \Rightarrow\right. \\
& \Rightarrow\left\{\begin{array}{l}
\dot{x}_{G_{3}}=\dot{x}_{D}-s_{3^{\prime}} \cdot \sin \phi_{3^{\prime}} \cdot \dot{\phi}_{3} \\
\dot{y}_{G_{3}}=\dot{y}_{D}+s_{3^{\prime}} \cdot \cos \phi_{3^{\prime}} \cdot \dot{\phi}_{3}
\end{array} \Rightarrow\right. \\
& \Rightarrow\left\{\begin{array}{l}
\ddot{x}_{G_{3}}=\ddot{x}_{D}-s_{3^{\prime}} \cdot \cos \phi_{3^{\prime}} \cdot \omega_{3}^{2}-s_{3^{\prime}} \cdot \sin \phi_{3^{\prime}} \cdot \varepsilon_{3} \\
\ddot{y}_{G_{3}}=\ddot{y}_{D}-s_{3^{\prime}} \cdot \sin \phi_{3^{\prime}} \cdot \omega_{3}^{2}+s_{3^{\prime}} \cdot \cos \phi_{3^{\prime}} \cdot \varepsilon_{3}
\end{array}\right.
\end{aligned}
$$

For the last two scalar components of the internal force from the joint $C$, one writes a new balance of forces on element 2 (for example), designed separately on axes $x$ and $y$ (system 7).

We obtained directly the internal forces $R_{23}^{x}$ and $R_{23}^{y}$. Their opposites, $R_{32}^{x}$ and $R_{32}^{y}$, they will be equal but opposite directed their, or in other words will have the same value but opposite sign.

For that all kinetostatic calculations of the $3 \mathrm{R}$ dyad to be possible, must be determined in advance, the forces and moments of inertia, separately for each element of the dyad. These are called, the group of the inertial forces" and are expressed with the relations system (8).

\section{Results}

The joints forces can be determined and represented by the two diagrams below (Fig. 2 and 3). 


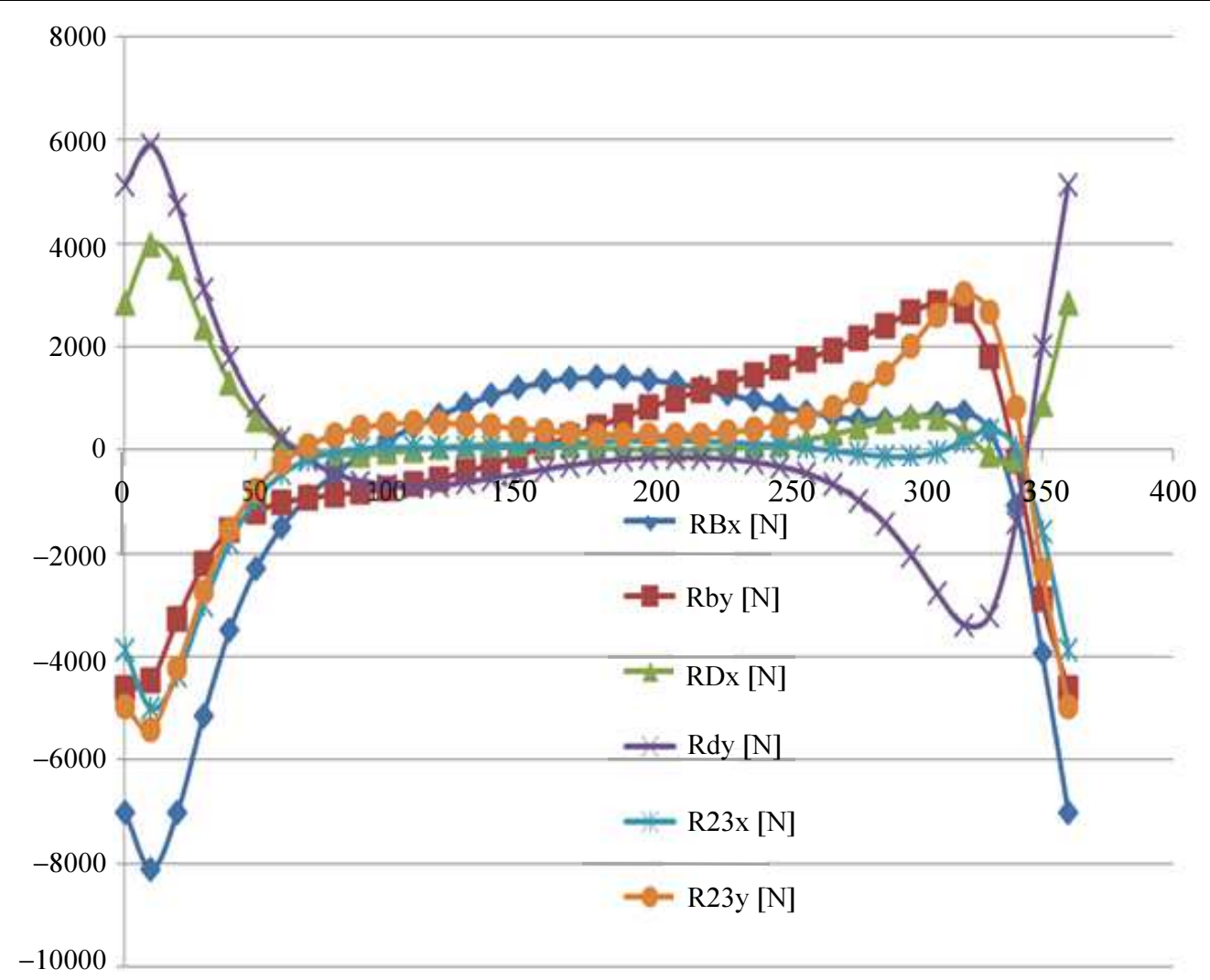

Fig. 2: The six internal forces of joints; $\omega=200\left[\mathrm{~s}^{-1}\right]$

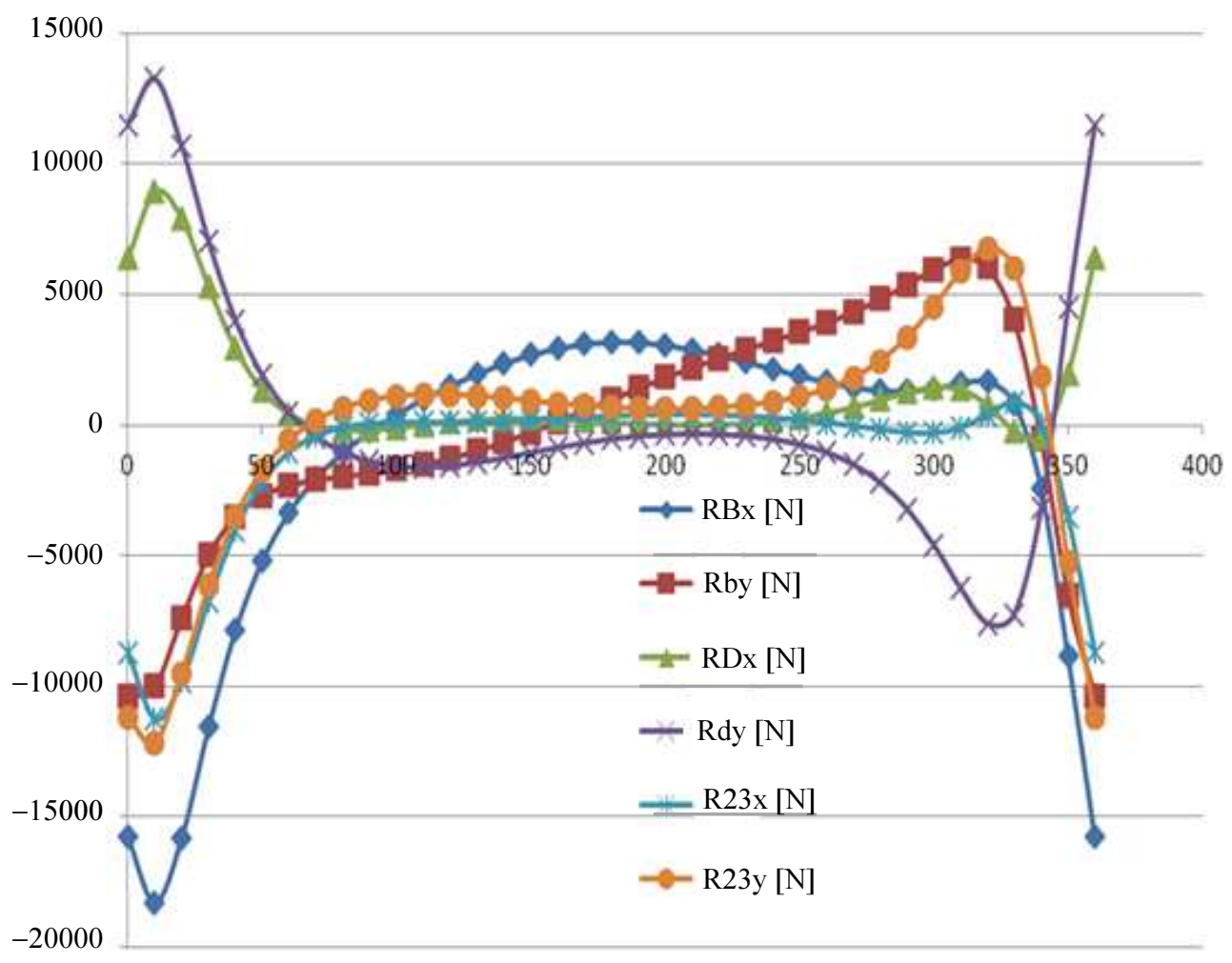

Fig. 3: The six internal forces of joints; $\omega=300\left[\mathrm{~s}^{-1}\right]$ 
Below you can see the six forces (internal forces) of joints from dyad 3R, depending on the angle of the crank FI, when the dyad is linked together with a crank, forming a mechanism $4 \mathrm{R}$.

Variation is represented on an entire cycle kinematic, for an angular velocity of crank, 200 or $300\left[^{-1}\right]$.

\section{Discussion}

$\mathrm{T}$ I-The first use of the reaction forces from couplings, is sizing of the kinematic couplings.

II-At the mechanisms with a degree of mobility, with the forces from driving coupling $\left(R_{B}^{x}, R_{B}^{y}\right)$, it determines the required motor torque $\left(M_{m}\right)$. We illustrate by the mechanism articulated quadrilateral (Fig. 4 and relationships 9):

$$
\left\{\begin{array}{l}
M_{m}-R_{21}^{x} \cdot\left(y_{B}-y_{A}\right)+R_{21}^{y} \cdot\left(x_{B}-x_{A}\right)=0 \Rightarrow \\
\Rightarrow M_{m}=R_{21}^{x} \cdot\left(y_{B}-y_{A}\right)-R_{21}^{y} \cdot\left(x_{B}-x_{A}\right) \Rightarrow \\
\Rightarrow M_{m}=-R_{12}^{x} \cdot\left(y_{B}-y_{A}\right)+R_{12}^{y} \cdot\left(x_{B}-x_{A}\right) \Rightarrow \\
\Rightarrow M_{m}=-R_{B}^{x} \cdot\left(y_{B}-y_{A}\right)+R_{B}^{y} \cdot\left(x_{B}-x_{A}\right)
\end{array}\right.
$$

Usually the torques $M_{1}$ and $M_{2}$ are null. But they can be and an external torque. III-At the mechanisms with two degree of mobility, with the forces from driving coupling (Fig. 5), it determines the required motor torques: $M_{1} \equiv M_{m 2}, M_{2} \equiv M_{m 3}$.
This scheme is used in anthropomorphic robots. Coupling $B$ is denoted by $O_{2}$. Coupling $C$ is denoted by $O_{3}$. Coupling $D$ become an end effector point $M$. Basic structure 3R of anthropomorphic robot (Fig. 6) can be decomposed into $2 \mathrm{R}$ planar structure (Fig. 5) which also possesses an additional rotating around a vertical axis $\left(O_{0} O_{1}\right)$.

It is more convenient to study the structure plan $\mathrm{O}_{2} \mathrm{O}_{3}$ $M$ system (elements 2 and 3 ). But since this system (plan, 2R) using balanced, it's good to study in its balanced form (Fig. 7).

Masses and lengths of the system are calculated using the Equation 10. Forces from the driveline balanced plan can be seen in the Fig. 8:

$$
\left\{\begin{array}{l}
\left\{\begin{array}{l}
\sum M_{O_{3}}^{(3)}=0 \Rightarrow \\
\Rightarrow m_{s} \cdot d_{3}+m_{3} \cdot s_{3}=m_{I I} \cdot \rho_{3} \\
\Rightarrow \rho_{3}=\frac{m_{s} \cdot d_{3}+m_{3} \cdot s_{3}}{m_{I I I}} \\
m_{3^{\prime}}=m_{3}+m_{s}+m_{I I I}
\end{array}\right. \\
\left\{\begin{array}{l}
\sum M_{O_{2}}^{(2+3)}=0 \Rightarrow \\
\Rightarrow m_{3^{\prime}} \cdot d_{2}+m_{2} \cdot s_{2}=m_{I I} \cdot \rho_{2} \\
\Rightarrow \rho_{2}=\frac{m_{3^{\prime}} \cdot d_{2}+m_{2} \cdot s_{2}}{m_{I I}} \\
m_{2^{\prime}}=m_{3^{\prime}}+m_{2}+m_{I I}
\end{array}\right.
\end{array}\right.
$$

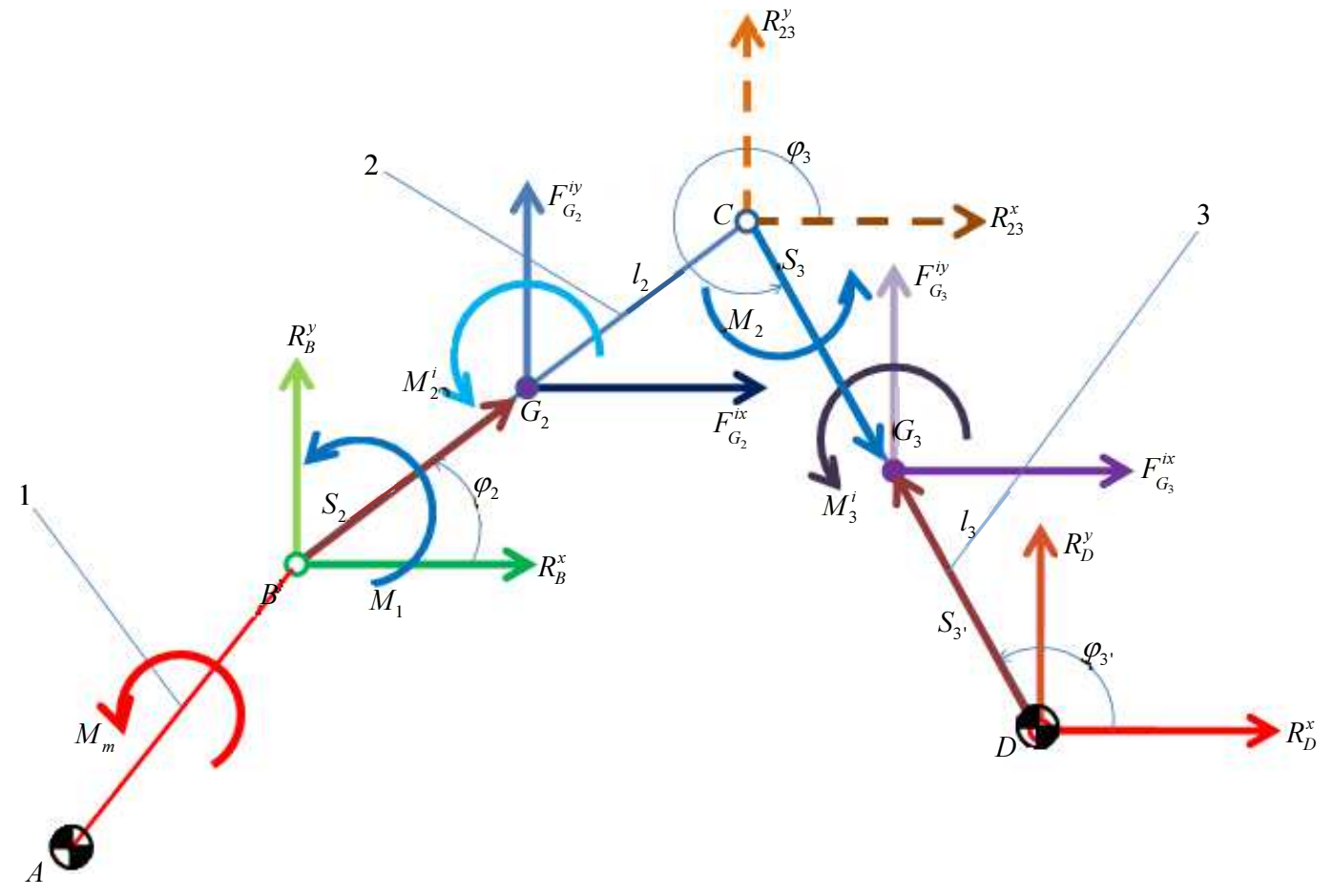

Fig. 4: The forces at a mechanism articulated quadrilateral 


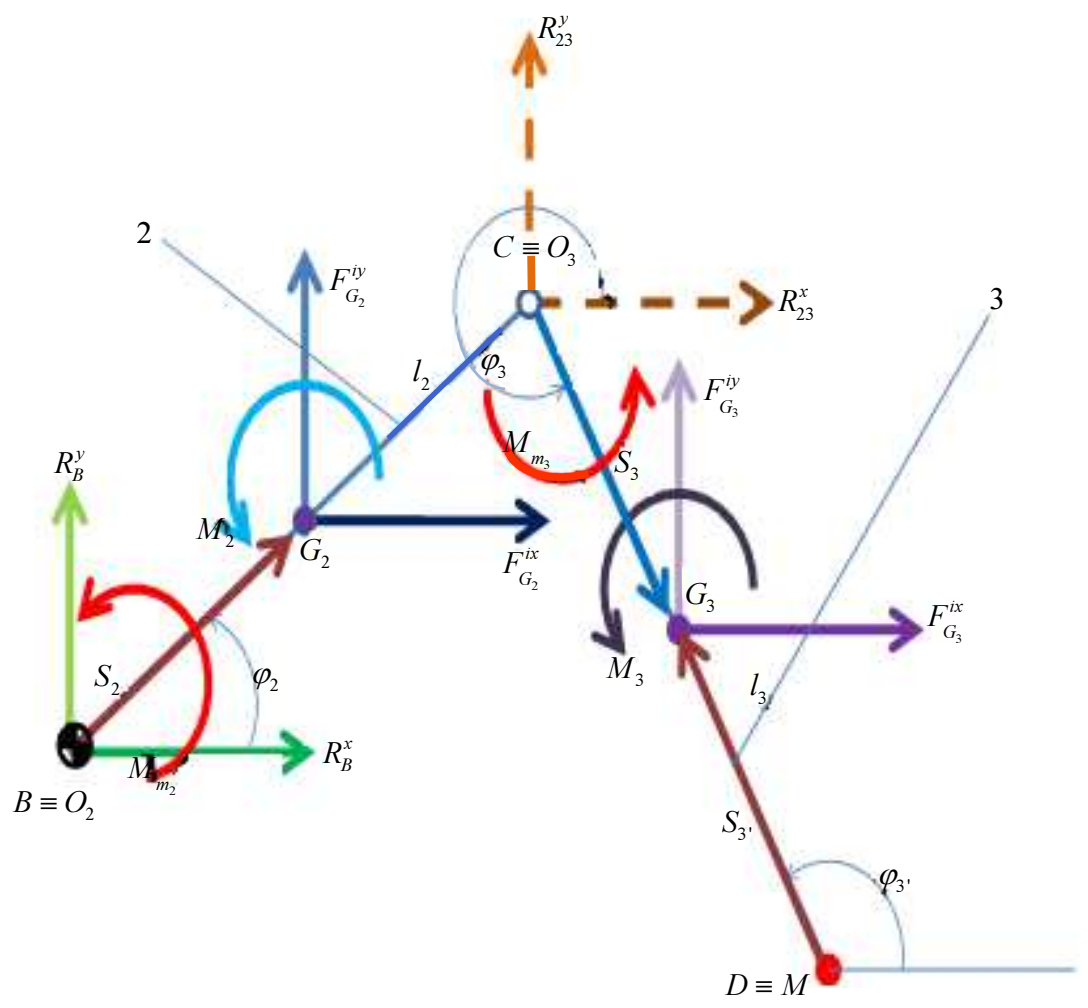

Fig. 5: The forces at a mechanism with two degree of mobility

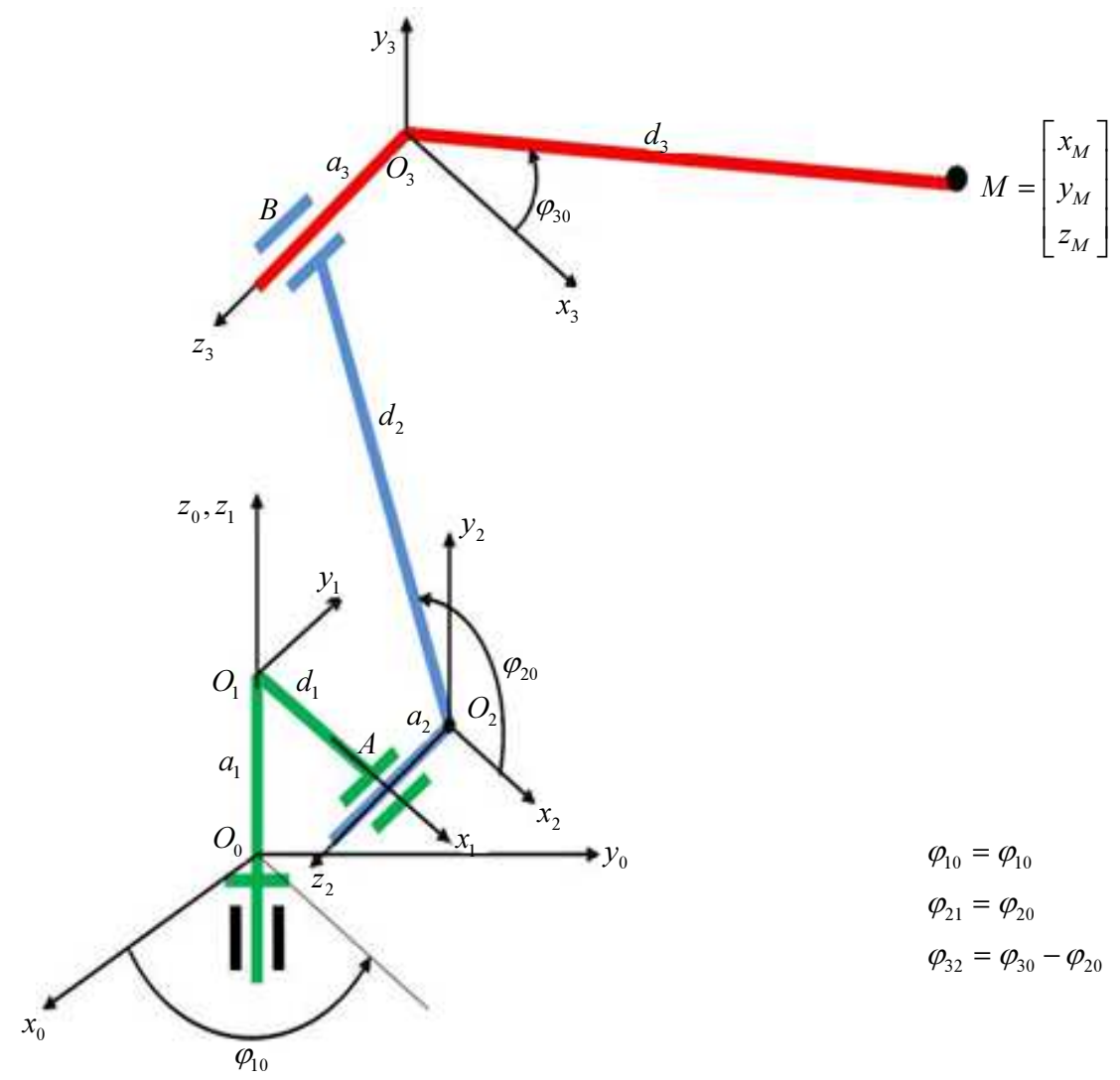

Fig. 6: The basic structure $3 R$ 


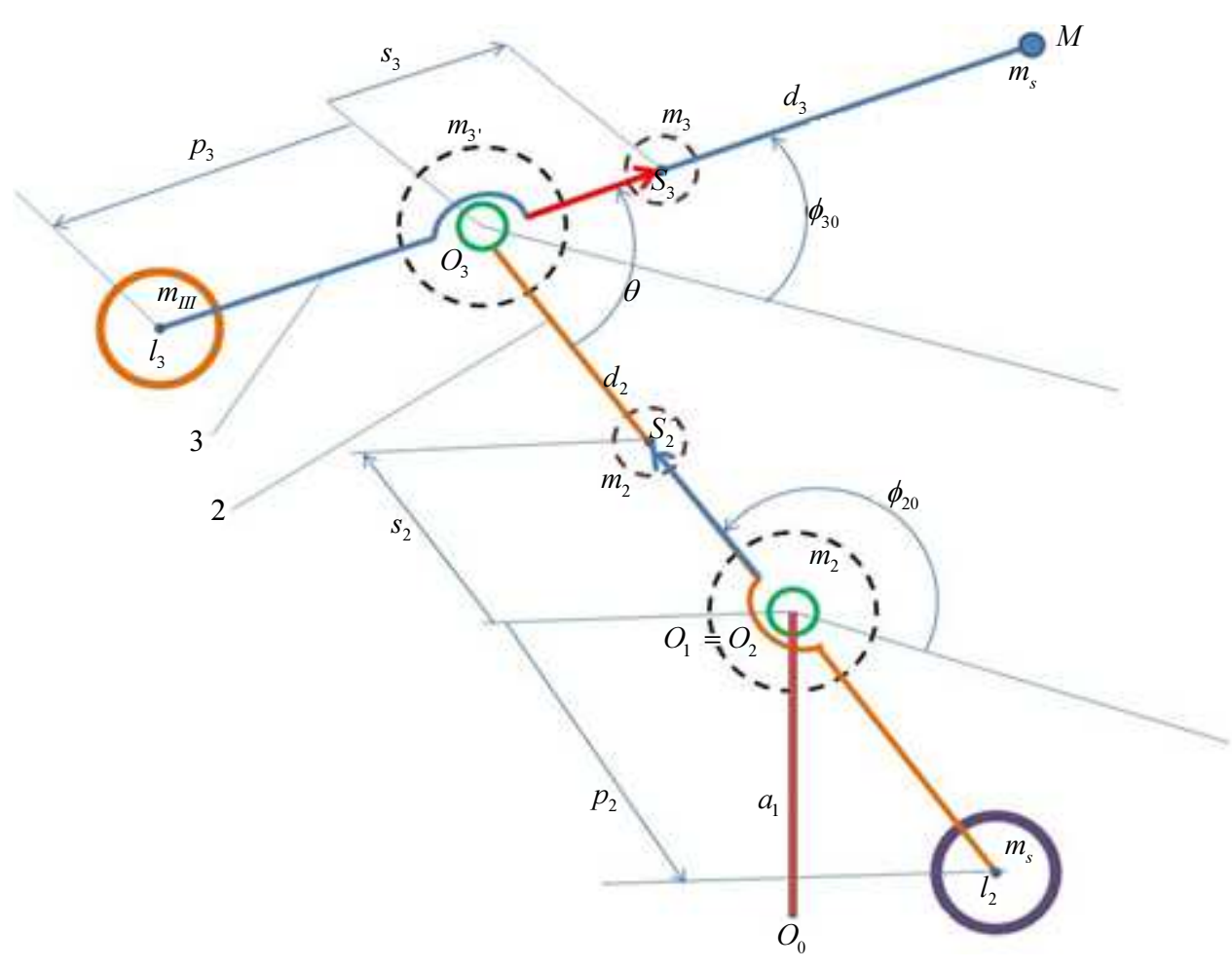

Fig. 7: The basic, balanced, structure $2 \mathrm{R}$

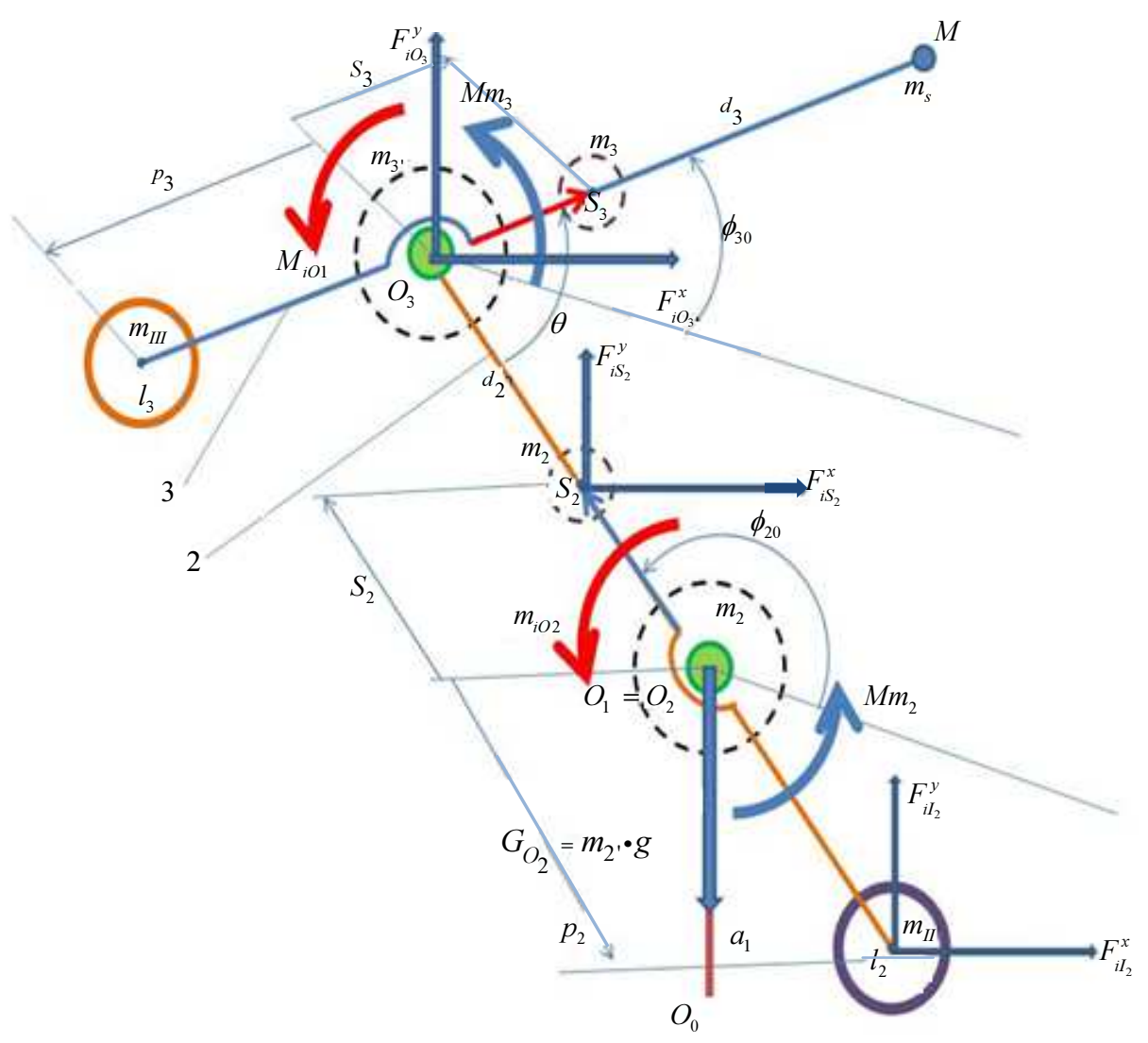

Fig. 8: The forces of the basic (balanced) structure $2 \mathrm{R}$ 
Now, it still writing inertial forces (relations system 11) of the point $O_{3}$ :

$$
\left\{\begin{array}{l}
F_{i O_{3}}^{x}=-m_{3^{\prime}} \cdot \ddot{x}_{O_{3}}= \\
=-m_{3^{\prime}} \cdot(-) d_{2} \cdot \cos \phi_{20} \cdot \omega_{20}^{2}= \\
=m_{3^{\prime}} \cdot d_{2} \cdot \cos \phi_{20} \cdot \omega_{20}^{2} \\
F_{i O_{3}}^{y}=-m_{3^{\prime}} \cdot \ddot{y}_{O_{3}}= \\
=-m_{3^{\prime}} \cdot(-) d_{2} \cdot \sin \phi_{20} \cdot \omega_{20}^{2}= \\
=m_{3^{\prime}} \cdot d_{2} \cdot \sin \phi_{20} \cdot \omega_{20}^{2} \\
M_{i O_{3}}=-J_{O_{3}} \cdot \varepsilon_{3}
\end{array}\right.
$$

Now we are writing and the inertial forces of the points $S_{2}(12)$ and $I_{2}(13)$ :

$$
\begin{gathered}
\left\{\begin{array}{l}
F_{i S_{2}}^{x}=-m_{2} \cdot \ddot{x}_{S_{2}}=m_{2} \cdot s_{2} \cdot \cos \phi_{20} \cdot \omega_{20}^{2} \\
F_{i S_{2}}^{y}=-m_{2} \cdot \ddot{y}_{S_{2}}=m_{2} \cdot s_{2} \cdot \sin \phi_{20} \cdot \omega_{20}^{2}
\end{array}\right. \\
\left\{\begin{array}{l}
F_{i I_{2}}^{x}=-m_{I I} \cdot \ddot{x}_{I_{2}}=-m_{I I} \cdot \rho_{2} \cdot \cos \phi_{20} \cdot \omega_{20}^{2} \\
F_{i I_{2}}^{y}=-m_{I I} \cdot \ddot{y}_{I_{2}}=-m_{I I} \cdot \rho_{2} \cdot \sin \phi_{20} \cdot \omega_{20}^{2}
\end{array}\right.
\end{gathered}
$$

Now we can write the equilibrium equations on the element 2 projected on the $x$ (system 14) and $y$ (system 15):

$$
\begin{aligned}
& \left\{\begin{array}{l}
\sum F_{(2)}^{x}=0 \Rightarrow m_{3^{\prime}} \cdot d_{2} \cdot \cos \phi_{20} \cdot \omega_{20}^{2}+m_{2} \cdot s_{2} \cdot \cos \phi_{20} \cdot \omega_{20}^{2}- \\
-m_{I I} \cdot \rho_{2} \cdot \cos \phi_{20} \cdot \omega_{20}^{2}+R_{O_{2}}^{x}=0 \Rightarrow \\
\Rightarrow\left(m_{3^{\prime}} \cdot d_{2}+m_{2} \cdot s_{2}-m_{I I} \cdot \rho_{I I}\right) \cdot \cos \phi_{20} \cdot \omega_{20}^{2}+R_{12}^{x}=0 \\
\text { but } m_{3^{\prime}} \cdot d_{2}+m_{2} \cdot s_{2}-m_{I I} \\
\cdot \rho_{I I}=0 \text { because balanced } \Rightarrow \\
\Rightarrow R_{O_{2}}^{x} \equiv R_{12}^{x}=0
\end{array}\right. \\
& \left\{\begin{array}{l}
\sum F_{(2)}^{y}=0 \Rightarrow m_{3^{\prime}} \cdot d_{2} \cdot \sin \phi_{20} \cdot \omega_{20}^{2}+m_{2} \cdot s_{2} \cdot \sin \phi_{20} \cdot \omega_{20}^{2}- \\
-m_{I I} \cdot \rho_{2} \cdot \sin \phi_{20} \cdot \omega_{20}^{2}-m_{2^{\prime}} \cdot g+R_{12}^{y}=0 \Rightarrow \\
\Rightarrow\left(m_{3^{\prime}} \cdot d_{2}+m_{2} \cdot s_{2}-m_{I I} \cdot \rho_{I I}\right) \\
\cdot \sin \phi_{20} \cdot \omega_{20}^{2}-m_{2^{\prime}} \cdot g+R_{12}^{y}=0 \\
\text { but } m_{3^{\prime}} \cdot d_{2}+m_{2} \cdot s_{2}-m_{I I} \cdot \rho_{I I}=0 \text { because balanced } \Rightarrow \\
\Rightarrow R_{O_{2}}^{y} \equiv R_{12}^{y}=m_{2^{\prime}} \cdot g=G_{O_{2}}
\end{array}\right.
\end{aligned}
$$

It can be seen that the torque loads are minimal precisely because balancing. Effect given inertial forces (torques produced by these forces) cancel (balance due).

Torques produced by the forces of gravity is canceled and they all balance due.

Balanced final weight also makes the power train only one effect, a vertical load (causes a vertical reactor) in fixed coupling.

At a total balanced, even the horizontal load disappears.
It will still write an amount of moments to the fixed point $\mathrm{O}_{2}$, on the element 2 (system 16):

$$
\left\{\begin{array}{l}
\sum M_{O_{2}}^{(2)}=0 \Rightarrow M_{m_{2}}-F_{i O_{3}}^{x} \cdot d_{2} \cdot \cos \left(\phi_{20}-\frac{\pi}{2}\right)- \\
-F_{i O_{3}}^{y} \cdot d_{2} \cdot \sin \left(\phi_{20}-\frac{\pi}{2}\right) \\
-F_{i S_{2}}^{x} \cdot s_{2} \cdot \sin \phi_{20}-F_{i S_{2}}^{y} \cdot s_{2} \cdot-\cos \phi_{20}+ \\
+F_{i I_{2}}^{x} \cdot \rho_{2} \cdot \cos \left(\phi_{20}-\frac{\pi}{2}\right) \\
+F_{i I_{2}}^{y} \cdot \rho_{2} \cdot \sin \left(\phi_{20}-\frac{\pi}{2}\right)+M_{i O_{2}}=0 \Rightarrow \\
\Rightarrow M_{m_{2}}-m_{3^{\prime}} \cdot d_{2}^{2} \omega_{20}^{2} \cos \phi_{20} \\
\sin \phi_{20}+m_{3^{\prime}} \cdot d_{2}^{2} \omega_{20}^{2} \sin \phi_{20} \cos \phi_{20}- \\
-m_{2} \cdot s_{2}^{2} \cdot \omega_{20}^{2} \cdot \cos \phi_{20} \\
\cdot \sin \phi_{20}+m_{2} \cdot s_{2}^{2} \cdot \omega_{20}^{2} \cdot \sin \phi_{20} \cdot \cos \phi_{20}- \\
-m_{I I} \cdot \rho_{2}^{2} \cdot \omega_{20}^{2} \cos \phi_{20} \cdot \sin \phi_{20} \\
+m_{I I} \cdot \rho_{2}^{2} \cdot \omega_{20}^{2} \cdot \sin \phi_{20} \cdot \cos \phi_{20}- \\
-J_{O_{2}}^{*} \cdot \varepsilon_{2}=0 \Rightarrow M_{m_{2}}-J_{O_{2}}^{*} \cdot \varepsilon_{2}=0 \Rightarrow M_{m_{2}}=J_{O_{2}}^{*} \cdot \varepsilon_{2}
\end{array}\right.
$$

Mass moment of inertia (or mechanical) of the element 2, is calculated with relation 17 .

$J_{O_{2}}^{*}=J_{O_{2}}+m_{3^{\prime}} \cdot d_{2}^{2}=m_{2} \cdot s_{2}^{2}+m_{I I} \cdot \rho_{2}^{2}+m_{3^{\prime}} \cdot d_{2}^{2}$

One can determine now the torque required $\left(M_{m 2}\right)$, which must be generated by the actuator 2 (mounted in coupling $\mathrm{O}_{2}$ ); see the relation (18).

$M_{m_{2}}=J_{O_{2}}^{*} \cdot \varepsilon_{2}=\left(m_{2} \cdot s_{2}^{2}+m_{I I} \cdot \rho_{2}^{2}+m_{3^{\prime}} \cdot d_{2}^{2}\right) \cdot \ddot{\phi}_{20}$

We now sum of the moments of all forces on item 3 in relation to swivel $O_{3}$ (relationship 19):

$$
\begin{aligned}
& \sum M_{O_{3}}^{(3)}=0 \Rightarrow \\
& M_{m_{3}}+M_{i O_{3}}=0 \Rightarrow M_{m_{3}}-J_{O_{3}} \cdot \varepsilon_{3}=0 \Rightarrow \\
& \Rightarrow M_{m_{3}}=J_{O_{3}} \cdot \varepsilon_{3} \Rightarrow \\
& \Rightarrow M_{m_{3}}=\left(m_{s} \cdot d_{3}^{2}+m_{3} \cdot s_{3}^{2}+m_{I I I} \cdot \rho_{3}^{2}\right) \cdot \ddot{\phi}_{30}
\end{aligned}
$$

One determines now and the vertical component, of the reaction, from the mobile (internal) coupling $\mathrm{O}_{3}$; (see the relations of the system 20).

$$
\left\{\begin{array}{l}
\sum F_{(3)}^{y}=0 \Rightarrow-m_{3^{\prime}} \cdot g+R_{23}^{y}=0 \Rightarrow \\
\Rightarrow R_{23}^{y}=m_{3^{\prime}} \cdot g \Rightarrow \\
\Rightarrow R_{32}^{y}=-R_{23}^{y}=-m_{3^{\prime}} \cdot g
\end{array}\right.
$$

Horizontal component (of the reaction from the kinematic coupling $O_{3}$ ) is zero (21). 


$$
R_{23}^{x}=-R_{32}^{y}=0
$$

There is no unanimously accepted definition of the robot. According to some specialists, this is related to the notion of movement and others associate the robot with the notion of the flexibility of the mechanism, its ability to be used for different activities or the notion of adaptability, the possibility of its operation in an unpredictable environment. Each of these notions taken separately can only characterize the robot partially.

The robot combines mechanical and electronic technology as an advanced automation component that encompasses cybernetic electronics with advanced drive systems to produce independent, highly flexible equipment.

The word "robot" first appeared in the R.U.R. (Rossum's Universal Robot) written by Czech playwright Karel Capek in which the author parodies the word "robot" (work in Russian and Czech choreography). In 1923 the song was translated into English, the word robot passed unchanged in all languages to define humanoid protagonists of science fiction stories.

The history of robotics begins in 1940 with the realization of synchronous manipulators for handling objects in radioactive environments. In 1954, Kenward of England patented a two-arm manipulator.

The concept of industrial robots was first established by George C. Deval, who patented in 1954 an automatic transfer device, developed in 1958 by American firm Consolidated Control Inc.

In 1959, Joseph Engelberger acquired Deval's patent and in 1960 he made the first R.I. Unimate at Unimation Inc.

The epic of industrial robots began in 1963 when the first industrial robot at General Motors' Trenton (US) plant was put into operation.

The first industrial success occurred in 1968 when the first car welding line was installed at the Lordstown plant, equipped with 38 Unimate robots. It turned out that the robot was the best spot welding machine.

By associating with Kawasaki N.I. in 1968, Japan began manufacturing the Unimate robots, their implementation in the automotive industry taking place in 1971 at Nissan-Motors.

In the same year, Unimate robots entered Italy, equipping the bodywork welding line at FIAT points in Turin.

Unimation and General Motors launched the PUMA (Programmable Universal Machine for Assembly) robot in 1978.

A.S.E.A. in Sweden, in 1971, the Irb6 industrial electric robot is designed for electric arc welding.

In 1975, the Cincinnati Milacron Machine Tool Company (USA) builds a family of industrially-powered T3 (The Tomorrow's Tool) industrial robots, today widespread.

In our country, in 1980, the first RIP63 robot was manufactured at Automatica Bucharest according to the model of A.S.E.A. and the first industrial application with this electric arc welding robot of a chassis component of a bus was carried out in 1982 at the Bucharest Bus. Two years later, the robots were also implemented at the Bucharest Seminary. Scientific Coordination belonged to the "MEROTEHNICA" team from the "Theory of Mechanisms and Robots" Department of " the Politehnica University of Bucharest" under the leadership of the late Christian Pelecudi, the father of Romanian robotics and the founder of SRR (Romanian Society of Robotics) today ARR (Romanian Association of Robotics). The TMR team had 80 collaborations with the Japanese companies (and thanks to the late Prof. Bogdan Radu, many years ambassador of Romania to Japan); have been brought in and implemented in the country Fanuc robots (at the time of the last generation).

Another native robot is REMT-1 used in a flexible manufacturing cell at Electromotor Timisoara for chip cutting of electric motors. The Timisoara University Center has greatly expanded its applicative research (with micro-production of industrial robots) and thanks to the strong support of Romanian specialists of German nationality it benefited, having collaborative contracts (in research and production) even with Germany. Today ROMAT robots are manufactured in Timisoara.

Robots have developed by increasing the degree of equipment with artificial intelligence. To gather the information of an environment, the robots have tactile, force, video moments, etc. With this, the robot can create an image of the environment in which it evolves, relying on artificial perception.

The robot population in 1988 was: 109,000 RIs in Japan, 30,000 RIs in the US, 34,000 RIs in Western Europe, of which 12,900 RIs in Germany, 3,000 RIs in Russia (Approximately 190,000 industrial robots globally and about 10 million in 2010).

Classification of R.I.

Japan Industrial Robot Association (JIRA) classifies industrial robots according to the following criteria.

After input and learning:

1. Hand manipulator, which is directly man operated

2. A Sequential robot that has certain steps that obey a predetermined procedure that can be either fixed or variable as it cannot or can be easily changed

3. Robot playback - which is first learned by a man, he memorizes it and then repeats it as many times as necessary

4. A robot with numerical control (N.C. robot) - which performs the required operations according to the numerical information it receives about positions, sequences of operations and conditions

5. Intelligent robot - is the one who decides its behavior based on the information received from its sensors and its possibilities for recognition 
Remarks:

a) Simple manipulators (groups 1 and 2) generally have 2-3 degrees of freedom, their movements being controlled by different devices

b) Programmable robots (groups 3 and 4) have a number of degrees of freedom greater than 3 being independent of mediums, i.e., lacking sensory capabilities and working in open loop

c) Smart robots are equipped with sensory capabilities and work in a closed loop

After order and degree of development of artificial intelligence: Industrial robots are classified into generations or levels:

1. R.I. from generation 1 , acts on a flexible but preprogrammed program that can't be changed during the execution of operations

2. R.I. of the 2 nd generation is characterized by the fact that the flexible program preset by the programmer can be modified to a limited extent following specific environmental reactions

3. R.I. of the third generation has the ability to adapt themselves by means of logical devices, to a limited extent their own program to the specific conditions of the environment in order to optimize the operations they perform

After the number of degrees of freedom of movement of the robot: they can be 2 to 6 degrees of freedom, plus the additional movements of the prehension device (endeffector), for guiding the grip, detachment of the manipulated object, etc.

The six degrees of freedom that a robot can have are three translations along the coordinate axes and three rotations around them.

Anthropomorphic robots are today increasingly used in almost all industrial fields because of their ability to work without stopping without damage, including repetitive, tedious work that a man could not carry out. On the other hand, they can work 24 hours a day, 365 days a year, if needed without breaks, what no worker would be able to do.

Anthropomorphic robots can also work in toxic, chemical, nuclear, radioactive, or even mined fields. For this reason, they now have multiple applications in almost all fields of activity, industrial and not only. If at first they started because of the need to manipulate parts in the road vehicle industry and have developed especially due to the construction of industrial machines and especially the cars, today the anthropomorphic robots have entered all industrial, commercial and military fields with all kinds of applications, performing heavy, repetitive, dangerous work, without breaks.
Figure 1 shows a schematic diagram of $3 \mathrm{R}$ dyad kinetostatic (determination of static forces, loaded with inertial forces, considered external forces).

If there are additional external forces such as technological resistances, they will also be added. The forces acting within a mechanism are of particular importance in that they give the dimensions of the mechanism, the elements of the mechanism so that it can withstand all the static and dynamic loads during its operation. For this reason, it is important to know all the forces acting on the elements but especially on the kinematic couplers, both for the correct dimensioning of these elements and for the proper functioning of the respective mechanism.

Forces together with kinematics are, on the other hand, basic components of dynamic calculations for that mechanism. This is also true for robots. Science that deals with the determination of forces within a mechanism is called Kinetostatic. The calculations within a mechanism are made on the pieces of this mechanism called structural groups or structural modulus.

The structural modules of a mechanism are determined on the basis of the principle of eliminating the mobility of the respective group in the desmodromic mechanisms. The mobility of the mechanism is given either by other movable input elements that are added to the structural groups or to the robots by adding some actuators to the elements of a module.

Anthropomorphic robots have a very fast working speed and high travel speeds with good dynamics and high positioning precision, being preferred to other mobile mechanical systems. They are serial mobile mechanical structures. Parallel or mixed moving mechanical structures are particularly useful when more robust and stable work systems are needed and ultraprecise positioning, such as in the case of space stations, including telescopic, of medical devices used in operating groups, microchips, or in areas requiring very high precision of motion and positioning.

\section{Conclusion}

The work presents a method for determination of kinetostatic parameters in dyad $3 R$. It starts with the determination of the forces in the joints: $R_{B}, R_{D}, R_{23}$. To generalize the method including for the $2 \mathrm{R}$ robots, enter both the moments $M_{1}, M_{2}$. This module (2R) is the main module found in all rotating anthropomorphic robotic structures and similar mechatronic structures.

\section{Acknowledgement}

This text was acknowledged and appreciated by Dr. Veturia CHIROIU Honorific member of Technical Sciences Academy of Romania (ASTR) PhD supervisor in Mechanical Engineering. 


\section{Funding Information}

Research contract: 1-Research contract: Contract number 36-5-4D/1986 from 24IV1985, beneficiary CNST RO (Romanian National Center for Science and Technology) Improving dynamic mechanisms.

2-Contract research integration. 19-91-3 from 29.03.1991; Beneficiary: MIS; TOPIC: Research on designing mechanisms with bars, cams and gears, with application in industrial robots.

3-Contract research. GR 69/10.05.2007: NURC in 2762; theme 8: Dynamic analysis of mechanisms and manipulators with bars and gears.

4-Labor contract, no. 35/22.01.2013, the UPB, "Stand for reading performance parameters of kinematics and dynamic mechanisms, using inductive and incremental encoders, to a Mitsubishi Mechatronic System" "PN-IIIN-CI-2012-1-0389".

All these matters are copyrighted! Copyrights: 394qodGnhhtej, from 17-02-2010 13:42:18; 463-vpstuCGsiy, from 20-03-2010 12:45:30; 631-sqfsgqvutm, from 2405-2010 16:15:22; 933-CrDztEfqow, from 07-01-2011 $13: 37: 52$.

\section{Author's Contributions}

This section should state the contributions made by each author in the preparation, development and publication of this manuscript.

\section{Ethics}

Authors should address any ethical issues that may arise after the publication of this manuscript.

\section{References}

Antonescu, P. and F. Petrescu, 1985. Metodã analiticã de sintezã a mecanismului cu camã si tachet plat. In al IV-lea Simpozion international de teoria si practica mecanismelor. Bucuresti.

Antonescu, P. and F. Petrescu, 1989. Contributii la analiza cinetoelastodinamicã a mecanismelor de distributie. Bucuresti.

Antonescu, P., M. Oprean and F. Petrescu, 1985a. Contributii la sinteza mecanismului cu camã oscilantã si tachet plat oscilant. In al IV-lea Simpozion international de teoria si practica mecanismelor. Bucuresti.

Antonescu, P., M. Oprean and F. Petrescu, 1985b. La projection de la came oscillante chez les mechanismes a distribution variable. In a V-a Conferintã de motoare, automobile, tractoare si masini agricole. I-motoare si automobile, Brasov, noiembrie.
Antonescu, P., M. Oprean and F. Petrescu, 1986. Proiectarea profilului Kurz al camei rotative ce actioneazã tachetul plat oscilant cu dezaxare. In al III-lea Siopozion national de proiectare asistatã de calculator în domeniul mecanismelor si organelor de masini-PRASIC'86. Brasov, decembrie.

Antonescu, P., M. Oprean and F. Petrescu, 1987. Analiza dinamicã a mecanismelor de distributie cu came. In al VII-lea Simpozion national de roboti industriali si mecanisme spatiale. Bucuresti, octombrie.

Antonescu, P., M. Oprean and F. Petrescu, 1988. Sinteza analiticã a profilului Kurz, la cama cu tachet plat rotativ. Revista Constructia de masini, nr. 2., Bucuresti.

Antonescu, P., F. Petrescu and O. Antonescu, 1994. Contributii la sinteza mecanismului cu camã rotativã si tachet balansier cu vârf. PRASIC'94, Brasov.

Antonescu, P., F. Petrescu and D. Antonescu, 1997. Geometrical synthesis of the rotary cam and balance tappet mechanism. Bucuresti. 3: 23-23.

Antonescu, P., F. Petrescu and O. Antonescu, 2000a. Contributions to the synthesis of the rotary disc-cam profile. Pro 8th International Conference on the Theory of Machines and Mechanisms, (TMM' 00), Liberec, Czech Republic, pp: 51-56.

Antonescu, P., F. Petrescu and O. Antonescu, 2000b. Synthesis of the rotary cam profile with balance follower. Proceedings of the 8th Symposium on Mechanisms and Mechanical Transmissions, (MMT'00), Timişoara, pp: 39-44.

Antonescu, P., F. Petrescu and O. Antonescu, 2001. Contributions to the synthesis of mechanisms with rotary disc-cam. Pro 8th IFToMM International Symposium on Theory of Machines and Mechanisms, (TMM' 01), Bucharest, ROMANIA, pp: 31-36.

Aversa, R., R.V.V. Petrescu, A. Apicella and F.I.T. Petrescu, 2017a. Nano-diamond hybrid materials for structural biomedical application. Am. J. Biochemistry Biotechnology.

Aversa, R., R.V. Petrescu, B. Akash, R.B. Bucinell and J.M. Corchado et al., 2017b. Kinematics and forces to a new model forging manipulator. Am. J. Applied Sci., 14: 60-80.

Aversa, R., R.V. Petrescu, A. Apicella, F.I.T. Petrescu and J.K. Calautit et al., 2017c. Something about the $\mathrm{V}$ engines design. Am. J. Applied Sci., 14: 34-52.

Aversa, R., D. Parcesepe, R.V.V. Petrescu, F. Berto and G. Chen et al., 2017d. Process ability of bulk metallic glasses. Am. J. Applied Sci., 14: 294-301.

Aversa, R., R.V.V. Petrescu, B. Akash, R.B. Bucinell and J.M. Corchado et al., 2017e. Something about the balancing of thermal motors. Am. J. Eng. Applied Sci.

Aversa, R., F.I.T. Petrescu, R.V. Petrescu and A. Apicella, 2016a. Biomimetic FEA bone modeling for customized hybrid biological prostheses development. Am. J. Applied Sci., 13: 1060-1067. DOI: 10.3844 /ajassp.2016.1060.1067 
Aversa, R., D. Parcesepe, R.V. Petrescu, G. Chen and F.I.T. Petrescu et al., 2016b. Glassy amorphous metal injection molded induced morphological defects. Am. J. Applied Sci., 13: 1476-1482.

Aversa, R., R.V. Petrescu, F.I.T. Petrescu and A. Apicella, 2016c. Smart-factory: Optimization and process control of composite centrifuged pipes. Am. J. Applied Sci., 13: 1330-1341.

Aversa, R., F. Tamburrino, R.V. Petrescu, F.I.T. Petrescu and M. Artur et al., 2016d. Biomechanically inspired shape memory effect machines driven by muscle like acting NiTi alloys. Am. J. Applied Sci., 13: 1264-1271.

Aversa, R., E.M. Buzea, R.V. Petrescu, A. Apicella and M. Neacsa et al., 2016e. Present a mechatronic system having able to determine the concentration of carotenoids. Am. J. Eng. Applied Sci., 9: 1106-1111.

Aversa, R., R.V. Petrescu, R. Sorrentino, F.I.T. Petrescu and A. Apicella, 2016f. Hybrid ceramo-polymeric nanocomposite for biomimetic scaffolds design and preparation. Am. J. Eng. Applied Sci., 9: 1096-1105.

Aversa, R., V. Perrotta, R.V. Petrescu, C. Misiano and F.I.T. Petrescu et al., 2016g. From structural colors to super-hydrophobicity and achromatic transparent protective coatings: Ion plating plasma assisted $\mathrm{TiO}_{2}$ and $\mathrm{SiO}_{2}$ nano-film deposition. Am. J. Eng. Applied Sci., 9: 1037-1045.

Aversa, R., R.V. Petrescu, F.I.T. Petrescu and A. Apicella, 2016h. Biomimetic and evolutionary design driven innovation in sustainable products development. Am. J. Eng. Applied Sci., 9: 1027-1036.

Aversa, R., R.V. Petrescu, A. Apicella and F.I.T. Petrescu, 2016i. Mitochondria are naturally micro robots - a review. Am. J. Eng. Applied Sci., 9: 991-1002.

Aversa, R., R.V. Petrescu, A. Apicella and F.I.T. Petrescu, 2016j. We are addicted to vitamins $\mathrm{C}$ and E-A review. Am. J. Eng. Applied Sci., 9: 1003-1018.

Aversa, R., R.V. Petrescu, A. Apicella and F.I.T. Petrescu, 2016k. Physiologic human fluids and swelling behavior of hydrophilic biocompatible hybrid ceramo-polymeric materials. Am. J. Eng. Applied Sci., 9: 962-972.

Aversa, R., R.V. Petrescu, A. Apicella and F.I.T. Petrescu, 20161. One can slow down the aging through antioxidants. Am. J. Eng. Applied Sci., 9: 1112-1126.

Aversa, R., R.V. Petrescu, A. Apicella and F.I.T. Petrescu, 2016m. About homeopathy or «Similia Similibus Curentur 》. Am. J. Eng. Applied Sci., 9: 1164-1172.

Aversa, R., R.V. Petrescu, A. Apicella and F.I.T. Petrescu, 2016n. The basic elements of life's. Am. J. Eng. Applied Sci., 9: 1189-1197.

Aversa, R., F.I.T. Petrescu, R.V. Petrescu and A. Apicella, 2016o. Flexible stem trabecular prostheses. Am. J. Eng. Applied Sci., 9: 1213-1221.
Berto, F., R.V.V. Petrescu and F.I.T. Petrescu, 2016a. A review of recent results on $3 \mathrm{D}$ effects. Am. J. Eng. Applied Sci., 9: 1247-1260.

Berto, F., R.V.V. Petrescu and F.I.T. Petrescu, 2016b. Three-dimensional in bonded joints: A short review. Am. J. Eng. Applied Sci., 9: 1261-1268.

Berto, F., A. Gagani, R.V.V. Petrescu and F.I.T. Petrescu, 2016c. Key-hole notches in isostatic graphite: A review of some recent data. Am. J. Eng. Applied Sci., 9: 1292-1300.

Berto, F., A. Gagani, R. Aversa, R.V.V. Petrescu and A. Apicella et al., 2016d. Multiaxial fatigue strength to notched specimens made of 40CrMoV13.9. Am. J. Eng. Applied Sci., 9: 1269-1291.

Cao, W., H. Ding, Z. Bin and C. Ziming, 2013. New structural representation and digital-analysis platform for symmetrical parallel mechanisms. Int. J. Adv. Robotic Sys. DOI: 10.5772/56380

Comanescu, A., 2010. Bazele modelarii mecanismelor. 1st Edn., E. Politeh. Press, Bucureşti, pp: 274.

Dong, H., N. Giakoumidis, N. Figueroa and N. Mavridis, 2013. Approaching behaviour monitor and vibration indication in developing a General Moving Object Alarm System (GMOAS). Int. J. Adv. Robotic Sys. DOI: $10.5772 / 56586$

Franklin, D.J., 1930. Ingenious mechanisms for designers and inventors. Industrial Press Publisher.

He, B., Z. Wang, Q. Li, H. Xie and R. Shen, 2013. An analytic method for the kinematics and dynamics of a multiple-backbone continuum robot. IJARS. DOI: $10.5772 / 54051$

Lee, B.J., 2013. Geometrical derivation of differential kinematics to calibrate model parameters of flexible manipulator. Int. J. Adv. Robotic Sys. DOI: $10.5772 / 55592$

Lin, W., B. Li, X. Yang and D. Zhang, 2013. Modelling and control of inverse dynamics for a 5-DOF parallel kinematic polishing machine. Int. J. Adv. Robotic Sys. DOI: 10.5772/54966

Liu, H., W. Zhou, X. Lai and S. Zhu, 2013. An efficient inverse kinematic algorithm for a PUMA560-structured robot manipulator. IJARS. DOI: $10.5772 / 56403$

Mirsayar, M.M., V.A. Joneidi, R.V.V. Petrescu, F.I.T. Petrescu and F. Berto, 2017. Extended MTSN criterion for fracture analysis of soda lime glass. Eng. Fracture Mechanics, 178: 50-59. DOI: 10.1016/j.engfracmech.2017.04.018

Padula, F. and V. Perdereau, 2013. An on-line path planner for industrial manipulators. Int. J. Adv. Robotic Sys. DOI: 10.5772/55063

Perumaal, S. and N. Jawahar, 2013. Automated trajectory planner of industrial robot for pick-andplace task. IJARS. DOI: 10.5772/53940

Petrescu, F. and R. Petrescu, 1995a. Contributii la optimizarea legilor polinomiale de miscare a tachetului de la mecanismul de distributie al motoarelor cu ardere internã. Bucuresti. 1 : 249-256. 
Petrescu, F. and R. Petrescu, 1995b. Contributii la sinteza mecanismelor de distributie ale motoarelor cu ardere internã. Bucuresti. 1: 257-264.

Petrescu, F. and R. Petrescu, 1997a. Dinamica mecanismelor cu came (exemplificatã pe mecanismul clasic de distributie). Bucuresti. 3: 353-358.

Petrescu, F. and R. Petrescu, 1997b. Contributii la sinteza mecanismelor de distributie ale motoarelor $\mathrm{cu}$ ardere internã cu metoda coordonatelor carteziene. Bucuresti. 3: 359-364.

Petrescu, F. and R. Petrescu, 1997c. Contributii la maximizarea legilor polinomiale pentru cursa activã a mecanismului de distributie de la motoarele cu ardere internã. Bucuresti. 3: 365-370.

Petrescu, F. and R. Petrescu, 2000a. Sinteza mecanismelor de distributie prin metoda coordonatelor rectangulare (carteziene). Proceedings of the 8th National Conference With International Participation, (CIP' 00), Craiova, Romania, pp: 297-302.

Petrescu, F. and R. Petrescu, 2000b. Designul (sinteza) mecanismelor cu came prin metoda coordonatelor polare (metoda triunghiurilor). Proceedings of the 8th National Conference With International Participation, (CIP' 00), Craiova, Romania, pp: 291-296.

Petrescu, F. and R. Petrescu, 2002a. Legi de mişcare pentru mecanismele cu came. Proceedings of the Internațională Proiectarea Asistată de Calculator, Simpozion Național cu Participare, (SNP' 02), Braşov, pp: 321-326.

Petrescu, F. and R. Petrescu, 2002b. Elemente de dinamica mecanismelor cu came. Proceedings of the Internațională Proiectarea Asistată de Calculator, Simpozion Național cu Participare, (SNP' 02), Braşov, pp: 327-332.

Petrescu, F. and R. Petrescu, 2003. Câteva elemente privind îmbunătățirea designului mecanismului motor. Proceedings of the Simpozion National, de Geometrie Descriptivă, Grafică Tehnică şi Design, (GTD' 03), Braşov, pp: 353-358.

Petrescu, F. and R. Petrescu, 2005a. The cam design for a better efficiency. Proceedings of the International Conference on Engineering Graphics and Design, (EGD' 05), Bucharest, pp: 245-248.

Petrescu, F. and R. Petrescu, 2005b. Contributions at the dynamics of cams. Proceedings of the Ninth IFToMM International Symposium on Theory of Machines and Mechanisms, (TMM' 05), Bucharest, Romania, pp: 123-128.

Petrescu, F. and R. Petrescu, 2005c. Determining the dynamic efficiency of cams. Proceedings of the Ninth IFToMM International Symposium on Theory of Machines and Mechanisms, (TMM' 05), Bucharest, Romania, pp: 129-134.

Petrescu, F. and R. Petrescu, 2005d. An original internal combustion engine. Proceedings of the Ninth IFToMM International Symposium on Theory of Machines and Mechanisms, (TMM' 05), Bucharest, Romania, pp: 135-140.
Petrescu, F. and R. Petrescu, 2005e. Determining the mechanical efficiency of Otto engine's mechanism. Proceedings of the Ninth IFToMM International Symposium on Theory of Machines and Mechanisms, (TMM 05), Bucharest, Romania, pp: 141-146.

Petrescu, F.I. and R.V. Petrescu, 2011. Mechanical Systems, Serial and Parallel (Romanian). 1st Edn., LULU Publisher, London, UK, pp: 124.

Petrescu, F.I. and R.V. Petrescu, 2012a. Kinematics of the planar quadrilateral mechanism. Engevista, 14: 345-348.

Petrescu, F.I. and R.V. Petrescu, 2012b MecatronicaSisteme Seriale si paralele. 1st Edn., Create Space Publisher, USA, pp: 128.

Petrescu, F.I. and R.V. Petrescu, 2013a. Cinematics of the 3R Dyad. Engevista, 15: 118-124.

Petrescu, F.I. and R.V. Petrescu, 2013b. Forces and efficiency of cams. Int. Rev. Mechanical Eng.

Petrescu, F.I. and R.V. Petrescu, 2016a. Parallel moving mechanical systems kinematics. ENGEVISTA, 18: 455-491.

Petrescu, F.I. and R.V. Petrescu, 2016b. Direct and inverse kinematics to the anthropomorphic robots. ENGEVISTA, 18: 109-124.

Petrescu, F.I. and R.V. Petrescu, 2016c. Dynamic cinematic to a structure 2R. Revista Geintec-Gestao Inovacao E Tecnologias, 6: 3143-3154.

Petrescu, R.V., R. Aversa, B. Akash, R. Bucinell and J. Corchado et al., 2017a. Yield at thermal engines internal combustion. Am. J. Eng. Applied Sci., 10: 243-251.

Petrescu, R.V., R. Aversa, B. Akash, B. Ronald and J. Corchado et al., 2017b. Velocities and accelerations at the 3R mechatronic systems. Am. J. Eng. Applied Sci., 10: 252-263.

Petrescu, R.V., R. Aversa, B. Akash, R. Bucinell and J. Corchado et al., 2017c. Anthropomorphic solid structures n-r kinematics. Am. J. Eng. Applied Sci., 10: 279-291.

Petrescu, R.V., R. Aversa, B. Akash, R. Bucinell and J. Corchado et al., 2017d. Inverse kinematics at the anthropomorphic robots, by a trigonometric method. Am. J. Eng. Applied Sci., 10: 394-411.

Petrescu, R.V., R. Aversa, B. Akash, R. Bucinell and J. Corchado et al., 2017e. Forces at internal combustion engines. Am. J. Eng. Applied Sci., 10: 382-393.

Petrescu, R.V., R. Aversa, B. Akash, R. Bucinell and J. Corchado et al., 2017f. Gears-Part I. Am. J. Eng. Applied Sci., 10: 457-472.

Petrescu, R.V., R. Aversa, B. Akash, R. Bucinell and J. Corchado et al., 2017g. Gears-part II. Am. J. Eng. Applied Sci., 10: 473-483.

Petrescu, R.V., R. Aversa, B. Akash, R. Bucinell and J. Corchado et al., 2017h. Cam-gears forces, velocities, powers and efficiency. Am. J. Eng. Applied Sci., 10: 491-505. 
Petrescu, R.V., R. Aversa, B. Akash, R. Bucinell and J. Corchado et al., 2017i. Dynamics of mechanisms with cams illustrated in the classical distribution. Am. J. Eng. Applied Sci., 10: 551-567.

Petrescu, R.V., R. Aversa, B. Akash, R. Bucinell and J. Corchado et al., 2017j. Testing by non-destructive control. Am. J. Eng. Applied Sci., 10: 568-583.

Petrescu, R.V., R. Aversa, A. Apicella and F.I.T. Petrescu, 2017k. Transportation engineering. Am. J. Eng. Applied Sci., 10: 685-702.

Petrescu, R.V., R. Aversa, S. Kozaitis, A. Apicella and F.I.T. Petrescu, 20171. The quality of transport and environmental protection, part I. Am. J. Eng. Applied Sci., 10: 738-755.

Petrescu, R.V., R. Aversa, A. Apicella and F.I. Petrescu, 2016. Future medicine services robotics. Am. J. Eng. Applied Sci., 9: 1062-1087.
Petrescu, F.I., B. Grecu, A. Comanescu and R.V. Petrescu, 2009. Some mechanical design elements. Proceeding of the International Conference on Computational Mechanics and Virtual Engineering, (MVE' 09), Braşov, pp: 520-525.

Petrescu, F.I., 2011. Teoria Mecanismelor si a Masinilor: Curs Si Aplicatii. 1st Edn., CreateSpace Independent Publishing Platform. ISBN-10: 1468015826. pp: 432.

Petrescu, F.I.T., 2015a. Geometrical synthesis of the distribution mechanisms. Am. J. Eng. Applied Sci., 8: 63-81.

Petrescu, F.I.T., 2015b. Machine motion equations at the internal combustion heat engines. Am. J. Eng. Applied Sci., 8: 127-137. 